\title{
The Influence of Openings on Energy Demand of Buildings: Analysis of their Characteristic Parameters Using LIDER Software (Spain)
}

\author{
Izaskun Gallo Ormazábal, Justo García Navarro, Trinidad Fernández \\ Pérez
}

\begin{abstract}
Openings on buildings façades perform several functions, namely, illumination, ventilation, vision, and communication with outside conditions. Furthermore, when energy efficiency is to be considered, the opening plays a major part in the energetic balance of a building. This article studies the opening as a specialized low technology system which regulates the external climatic conditions having an impact on the building energy demand. First, it was analysed the main parameters that characterize the opening as an element of solar reception in order to indentify the influence of each of them with regard to energy demand. By means of LIDER software calculation method the opening is studied as a solar gain element. LIDER is a recognized free computer programme of Spanish Building Regulation (Código Técnico de la Edificación, CTE). The contribution of 14 specific parameters of the opening to energy demand is evaluated, specifically, orientation, window-to-wall ratio, frame percentage, degree of absorption, glazing g-value, frame $U$-value, glazing U-value, overhangs, returns, louver blinds, awnings, air permeability, infiltration and air change rate. With this approach, it was obtained the relative relevance of the 14 parameters under study with regards to energy performance of a simulated space considering the conditions set in the analysis. The alteration in those parameters allows for variations in energy demand estimated at the range 10-60\% in heating, and between 2-150\% in cooling. The outcomes are more important in qualitative than in quantitative terms due to the limitations of the method and to the working hypotheses of the onset conditions.
\end{abstract}

Keywords: Opening Design, Sustainability, Energy-Efficiency, Energy Performance of Windows, Green Buildings, Fenestration

\section{Introduction}

$\mathrm{O}$ penings play an important role in the energy performance of a building so, special consideration should be taken during their design. The different functions that openings perform (ventilation, solar protection, daylighting, etc.) turn them into active control systems of the external conditions that can be conceived as specialized low technology systems (Mustieles et al. 1998). The opening can be designed so as to regulate the external climatic conditions by means of a set of elements which have specialized functions in a system, that of the window unit and its bioclimatic potential. Thus, by means of different bioclimatic techniques, the window can adjust the thermal conditions of spaces in a bioclimatic efficient way.

The problem stemming from the application of these techniques is the quantification of the energy that is saved as a result of their implementation. Methods have been developed in countries such as USA, United Kingdom, Denmark or Italy in order to meet the requirements for windows energy demands; to certify energy demands in construction products is a useful way to improve the energy performance of the whole building. In a Spanish research, about WERS (Window Energy Rating System) method to predict windows energy performance, savings up to 18.2-41.5 kWh/(m2 year) were accomplished for a building located in Bilbao (Spain). This study used opening ratio between $15-30 \%$, glazing transmittance between $2.8-0.55 \mathrm{~W} / \mathrm{m} 2 \mathrm{~K}$, g-value between 0.78-0.487 and solar heat gain coefficient between 0.65-0.41 (Urbikaín and Sala 2009, 687-695).

There are low-technology alternatives in use for many years that should be revisited and reinstated in order to use in a cautious way the present techno-scientific possibilities so that all three economic, social, and environmental criteria of sustainability are considered. The opening 
designed as a specialized system of low technology can bring great contributions to energy efficiency and also to sustainability. Consequently, it is important to design tools in order to quantify the thermal contribution of the opening to the building without restricting its design possibilities.

This article researches into the opening design from the viewpoint of its contribution to the thermal performance of a building. The aim is to value the contribution to the energy balance of a given space that depends on the opening by means of the analysis of different opening configurations. The main parameters with a potential for improvement of openings as regards a better climatic adaptability of the building are studied. Thus, different opening shapes considering the studied parameters are analysed. The energy demand in heating and cooling systems for the different configurations is calculated; then, their respective outputs are compared and finally the variation percentages of the demand are obtained, associating them with the parameters under evaluation.

This analysis permits to compare the contribution of each parameter to the energy performance of a building. Obtained results may as well be useful when setting up priorities in decision-making processes that affect the design of the openings in a building, both for new buildings as for renovation.

\section{Background Information}

Bioclimatic, solar or passive architecture offers environmental conditioning techniques for both heating and cooling that might save about 50\% in energy consumption (Yáñez 2008). The average energy consumption per household in one year is estimated to be 13,038 kWh (Cuchí 2010), 1.12 toe per house, which amounts to emissions of $\mathrm{CO}_{2}$ of $3.43 \mathrm{tCO}_{2}$ per year, considering a conversion factor for oil types A, B or C $3.06 \mathrm{tCO}_{2}$ /toe (IDAE 2013). Around $50 \%$ of this consumption $(6,519 \mathrm{kWh})$ is assigned to space heating and cooling and illumination (Cuchí 2010). According to these estimations, the adoption of construction solutions which included sustainable thermal and lighting good practices would reduce consumption by $3,259.5 \mathrm{kWh}$, which in turn would imply reducing the emissions of $\mathrm{tCO}_{2}$ by 0.86 per household/year. This significant figure encourages the use of these techniques for building refurbishment. Actually, to achieve these figures in renovation is very difficult and complex due to town planning concerns, regulation restrictions, economic and functional demands, and also quantification difficulties. However, encouraging results have been obtained in European research projects on building restoration considering solar energy.

The analysis of 14 pilot projects in several cities in central Europe ascribed to the Solar Heating and Cooling Programme of the International Energy Agency (IEA), Task 20 'Solar Energy in Building Renovation', shows that adopting solar efficiency techniques is clearly cost and effort-effective from the financial, the technical and the architectural viewpoint within the context of comprehensive restoration. The energy savings obtained in those projects were between 3\% and 70\% (Voss 2000, 291-302). For example, for glazed balconies -one of the systems used- there was an annual energy saving between $10-20 \mathrm{kWh} / \mathrm{m}^{2}$ and between $5-10$ $\mathrm{kWh} / \mathrm{m}^{2}$ of solar gain per square metre of heated surface (International Energy Agency 1999). Another study analyzing the advantages and disadvantages of the passive use of solar energy in buildings demonstrates annual energy savings due to unique solar considerations of restoration of between 10-50 kWh/m² (Dalenbäck 1996, 39-50).

With sole regard to solar heating passive systems, three types of basic systems can be found: direct gain, indirect gain and attached sunspace or conservatory (Yáñez 2008). These three systems are similar in that they gain solar radiation through a glazed opening. The interaction of this solar radiation with the other construction elements, forming each system, produces an input of heat energy. In Southern European countries, where winters are often mild, the opening can 
prove a source of heat energy and bring on a substantial decrease in energy consumption for heating by means of variations in architectural design.

According to Leal and Maldonado (Leal and Maldonado 2008, 217-227), most windows can be modelled by existing thermal and energy simulation programs. However, it is often difficult to integrate innovative elements in such programs, and the way integration is carried out commonly turns out to be inappropriate. Even when the innovative element can be simulated by the program, it is important to have experimental data to help with the calibration of the models or, if necessary, to develop new simulation models for that element and its integration within the whole simulation of the building. Furthermore, experimental data can be useful to adjust the modelling approach and parameters.

Determining about whether opening elements are traditional or innovative is not so straightforward. It depends, to some extent, on the parameters to be considered when solving the complex problem of the thermal balance of a window. For example, Fissore and Fonseca (Fissore and Fonseca 2007, 3309-3321) have investigated a theoretical model for the thermal performance of a window with a traditional type of indoor protection. By means of experimental analysis, the above mentioned authors calibrate the great variety of parameters that affect the thermal balance of a window to estimate energy savings for different configurations of windows with traditional elements such as blinds and curtains. So, they have detected $24 \%$ less heat consumption when using a blind, in comparison to a similar case for a curtain. From experimental results, they established a model that allows calculating the convective heat transfer coefficient and the air flow rate entering to the window cavity formed between the glazing surface and the protection device (Cuevas, Fissore, and Fonseca 2010, 1685-1691).

Air flow effect is not considered in most energy simulation tools. SOLVENT window (Erell et al. 2004, 467-480) is an innovative glazing system concept consisting of a reversible frame, an absorptive glazing and a vertical ventilated channel aimed to improve the balance between visual comfort and energy efficiency of windows. It attempts to reconcile conflicting requirements such as visual comfort and thermal performance, which architectural design has to tackle in Mediterranean countries. In these countries, winters are cold enough to require using solar energy for space heating whereas summer conditions require maximum protection against solar radiation. A computerized tool was developed to assist architects and lighting consultants in different design options. To develop this innovative glazing system it was necessary to install a prototype of SOLVENT window in a PASLINK cell. Monitoring results were used to optimize and validate the model and it was also used in case studies. Theoretical models were supported by performed measurements to achieve realistic results (Leal and Maldonado 2008, 217-227).

\section{Methodology}

The different opening configurations analysed in this article do not incorporate innovative elements; they just include variables used in traditional design. Because of that, it is possible to use LIDER software (LIDER v1.0, 1/7/2009) in the calculation of energy demand. LIDER (Limitación de la Demanda de Energía - Energy Demand Limitation) software is used in Spanish Building Regulations to verify energy demand requirements according to Energy Savings Core Document (DB HE) of Technical Building Code (Código Técnico de la Edificación - CTE) (IETCC 2010b). LIDER is a recognized computer programme free of charge for public use. The calculation engine of LIDER, CDEEW.exe (Cálculo de Demanda de Energía de Edificios para Windows - Building Energy Demand Calculation for Windows), is the evolution of the simulation software S3PAS developed in Universidad de Sevilla (Spain). S3PAS was validated with the International Energy Agency Building Energy Simulation Test (BESTest) (AICIA 2009a). LIDER uses a dynamic and multizone detailed simulation model to perform calculations of heating and cooling needs of buildings. It employs a formalized calculation method that automatically accomplishes calculations for energy demand described in DB HE, starting from 
building input data. This program allows modifying the values of different characteristic parameters of openings, so it can be used to assess how much those parameters favour or damage the global energy demand of a building.

The object under analysis is a generic space, namely, a cubic space part of a building made of basic construction elements fulfilling basic CTE requirements for the city of Madrid (Spain). Regarding quantification, the analysis has estimated the approximate range of the generic space energy demand dependent on the contribution of the different opening parameters.

Consequently, it might be interesting to validate some of the cases with experimental models such as PASLINK cell to get more realistic results in forthcoming research. Furthermore, it might be worthwhile to investigate on LIDER software limitations concerning the way it models openings within the global simulation of the building.

\section{Modeling the Opening in a Generic Space with LIDER Software}

The virtual space is a cube with an opening in one of its vertical envelope elements. The configuration of the opening was modified in different ways and stages so as to analyse the contribution of the opening to the energy demand of that cubic space. Opening construction and geometrical characteristics were changed according to different combinations of the 14 parameters that were analysed to a maximum of 430 different cases. These 14 parameters are: orientation, window-to-wall ratio, frame percentage, degree of absorption, glazing g-value, frame U-value, glazing U-value, overhangs, returns, louver blinds, awnings, air permeability, infiltration and air change rates.

LIDER calculates thermal performance of a building on an hour basis, in transient regime, considering both external and internal conditions and considering the effects of thermal mass (AICIA 2009a). It compares the building under study with a reference building generated by the programme which exactingly fulfills Spanish Regulation requirements. Then it compares both of them giving results in terms of percentages of heating and cooling demand with respect to the reference building, and total percentages of heating and cooling demand of the building in the test.

Table 1: Climate, operation and construction elements input data

\begin{tabular}{|c|c|}
\hline & Input Data \\
\hline Climate & Climatic zone D3, Madrid (Spain) \\
\hline Operation & $\begin{array}{l}\text { Single-storey house, residential use, hygrometric level } 3 \text { or less and air } \\
\text { change rate } 1 / \mathrm{h}\end{array}$ \\
\hline \multirow[t]{3}{*}{$\begin{array}{l}\text { Construction } \\
\text { Elements }\end{array}$} & $\begin{array}{l}\text { Wall }\left(\mathrm{U}=0.34 \mathrm{~W} / \mathrm{m}^{2} \mathrm{~K}\right) \text { : Perforated clay brick }(\mathrm{d}=0.115 \mathrm{~m}) \text {, mortar } \\
\text { cement } 1000<\rho<1250(\mathrm{~d}=0.015 \mathrm{~m}) \text {, unventilated air cavity }(\mathrm{d}=0.02 \mathrm{~m}) \text {, } \\
\text { polyurethane insulating material } \lambda=0.028 \mathrm{~W} / \mathrm{mK}(\mathrm{d}=0.060 \mathrm{~m}) \text {, clay } \\
\text { brick }(\mathrm{d}=0.07 \mathrm{~m}) \text { and gypsum mortar } 1000<\rho<1300(\mathrm{~d}=0.015 \mathrm{~m}) \text {. }\end{array}$ \\
\hline & $\begin{array}{l}\text { Flat roof }\left(\mathrm{U}=0.26 \mathrm{~W} / \mathrm{m}^{2} \mathrm{~K}\right) \text { : Sand and gravel } 1700<\rho<2200(\mathrm{~d}=0.050 \\
\mathrm{m}) \text {, expanded polystyrene EPS } \lambda=0.032 \mathrm{~W} / \mathrm{mK}(\mathrm{d}=0.10 \mathrm{~m}) \text {, textile } \\
\text { protection layer }(\mathrm{d}=0.001 \mathrm{~m}) \text {, bituminous sheeting }(\mathrm{d}=0.02 \mathrm{~m}) \text {, textile } \\
\text { protection layer }(\mathrm{d}=0.001 \mathrm{~m}) \text {, lightweight concrete } \rho=1000 \mathrm{~kg} / \mathrm{m}^{3} \\
(\mathrm{~d}=0.10 \mathrm{~m}) \text { and reinforced concrete floor }(\mathrm{d}=250 \mathrm{~mm}) \text {. }\end{array}$ \\
\hline & $\begin{array}{l}\text { Floor in contact with earth }\left(\mathrm{U}=0.57 \mathrm{~W} / \mathrm{m}^{2} \mathrm{~K}\right) \text { : Artificial stone }(\mathrm{d}=0.03 \\
\mathrm{m}) \text {, cement mortar } 1000<\rho<1250(\mathrm{~d}=0.015 \mathrm{~m}) \text {, expanded polystyrene } \\
\text { EPS } \lambda=0.037 \mathrm{~W} / \mathrm{mK}(\mathrm{d}=0.04 \mathrm{~m}), \text { reinforced concrete } 2300<\rho<2500 \\
(\mathrm{~d}=0.15 \mathrm{~m}) \text {, gravel and sand } 1700<\rho<2200(\mathrm{~d}=0.25 \mathrm{~m}) \text { and } \\
\text { compressed earth } 1770<\rho<2000(\mathrm{~d}=0.20 \mathrm{~m}) \text {. }\end{array}$ \\
\hline
\end{tabular}


The characteristic parameters of openings in the study are those included in current Spanish building regulations, more particularly in the Spanish Building Code (CTE), Energy Savings Basic Document, Section HE 1 'Energy demand limitation'. For methodological purposes, these parameters have been classified in two groups divided in different categories depending on their features. The first group gathers those variables related to intrinsic architectural and constructive properties and the second group those related to architectonic and constructive elements of indoor environmental control.

Regarding the first group, firstly, measurement parameters were analysed, and different sizes of openings were combined with various percentages of frame and glazing, 72 cases in total. Secondly, aspects directly related to solar radiation performance, different degrees of absorption of the frame were combined with varied g-value of glazing, up to 54 cases. Finally, other cases combine materials with different properties: frame types with different $U$-values and glazing with various $\mathrm{U}$-values and g-values, up to 84 cases.

In the second group, different options of shading protection were combined: overhangs, returns, louver blinds and awnings, up to 171 cases. Finally, parameters related to ventilation were studied, some windows with different air permeability and different infiltration rate were combined ( 24 cases), and also windows with ventilators and different air change rates according to occupancy patterns ( 25 cases).

Obtained percentages from each set of cases have been compared for every orientation, calculating the difference between upper and lower values. Thus, an estimation of the degree of variation achieved modifying the parameters in the study is obtained.

\section{Description of Studied Parameters and Assigned Values}

The assigned values on each parameter should establish opening configurations with significant differences in order to distinguish the advantages amongst them. Empirical studies such as Fissore's (Fissore and Fonseca 2007, 3570-3581) have shown that, when differences between several window configurations are small, it is not possible to choose one above the others. The parameter values have been selected along with the values included in the Spanish Building Regulation (CTE).

\section{Parameters Regarding Dimensions, Direct Solar Radiation Performance, and Materials}

With respect to dimensions, on the one hand the opening proportion in relation to the opaque façade in four window-to-wall ratios has been studied: $0-20 \%, 21-40 \%, 41-60 \%$ and $>60 \%$ (CTE HE 1 Tables 22.2 Limit values of average characteristic parameters) (IETCC 2010b). On the other hand, the fraction of frame with respect to the opening area has been studied: $<15 \%, 15$ $30 \%$ y $30-50 \%$. These percentages were analysed following Margarita de Luxán's criteria (Luxán 2009).

Regarding parameters related directly to solar radiation performance, the first was orientation. This parameter has also been analysed in all the other categories, but it has been evaluated independently in this case. The orientations were retrieved from the CTE in DB HE1 [15(IETCC 2010b)]: North $(\alpha<60 ; \alpha 0 \geq 300)$, East $(60 \leq \alpha 0<111)$, Southeast $(111 \leq \alpha 0<162)$, South $(162 \leq \alpha 0<198)$, Southwest $(198 \leq \alpha 0<249)$, and West $(249 \leq \alpha 0<300) ; \alpha 0$ being the angle formed to the right of the North orientation and $\alpha$ the one to the left (Fig. 1). 


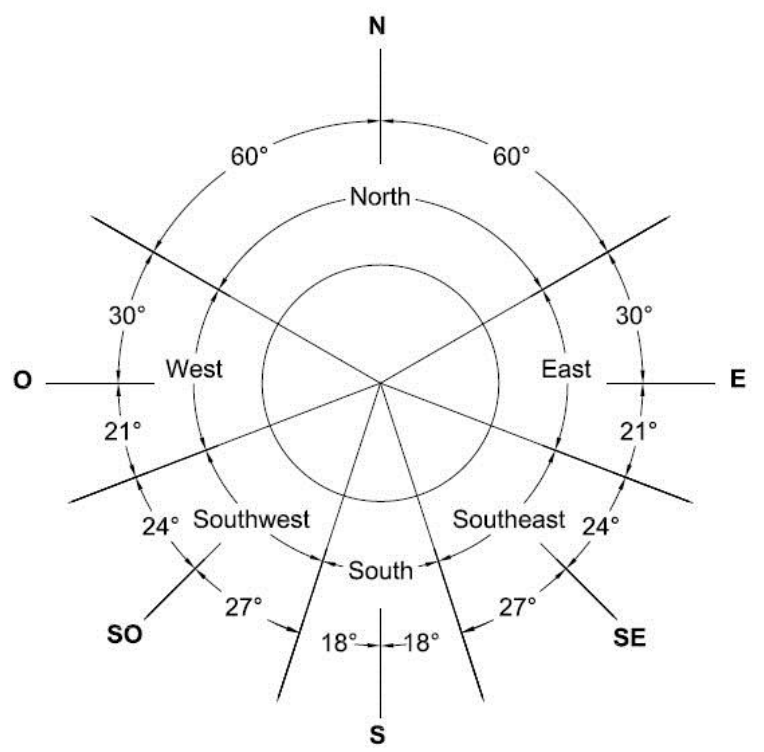

Figure 1: Orientation of façades

Source: CTE DB HE 1 (Figure 3.1)

The second parameter of this category is frame degree of absorption, which identifies the frame colour. Values have been selected from Table E.10 Frame degree absorption for solar radiation $\alpha$, in the CTE DB HE1 (IETCC 2010b). The following three representative colours of the same range have been selected: light white $(0.20)$, medium beige $(0.55)$ and dark blue $(0.95)$.

Finally, glazing g-value has been evaluated taking values from the classification for colourless glasses of the 'Catálogo de Elementos Constructivos' ('Catalogue of Construction Elements') Section 3.15 Glazings (IETCC 2010a): 0.83, 0.73 and 0.60 that correspond to three types of glazing: single, insulating and low emissive insulating glazing.

All the materials were analysed considering frame U-values, which were selected from LIDER database: wood frame of low-medium density $\mathrm{U}=2.00 \mathrm{~W} / \mathrm{m} 2 \mathrm{~K}$, wood frame of high medium density $\mathrm{U}=2.10 \mathrm{~W} / \mathrm{m} 2 \mathrm{~K}$, metal frame without thermal break $\mathrm{U}=5.70 \mathrm{~W} / \mathrm{m} 2 \mathrm{~K}$, metal frame with thermal break $4-12 \mathrm{~mm} \mathrm{U}=4.00 \mathrm{~W} / \mathrm{m} 2 \mathrm{~K}$, with thermal break metal frame $>12 \mathrm{~mm}$ $\mathrm{U}=3.20 \mathrm{~W} / \mathrm{m} 2 \mathrm{~K}$, PVC of double cavity $\mathrm{U}=2.20 \mathrm{~W} / \mathrm{m} 2 \mathrm{~K}$ and $\mathrm{PVC}$ of triple cavity $\mathrm{U}=1.80$ $\mathrm{W} / \mathrm{m} 2 \mathrm{~K}$.

Chosen glazings and their respective $\mathrm{U}$-values and g-values have been two medium standards: glazing 4(15)4 with standard internal and external panes $(\mathrm{U}=2.70 \mathrm{~W} / \mathrm{m} 2 \mathrm{~K}$, gvalue $=0.76)$ and glazing $4(15) 4$ with low emissivity $(<0.03)$ internal pane and standard external pane $(\mathrm{U}=1.40 \mathrm{~W} / \mathrm{m} 2 \mathrm{~K}, \mathrm{~g}$-value $=0.43)$.

\section{Parameters Regarding Shading Components and Ventilation}

Overhangs (horizontal and vertical) have been evaluated following the parameters established in the DB HE of CTE, Appendix E. Table E.11 Shading factor for façade obstructions (IETCC 2010b): $\mathrm{D}=0.20,0.50$ and $1.00 \mathrm{~m}$; and of $\mathrm{L}=0.50,0.80,1.50$ and $2.50 \mathrm{~m}$. D being the distance of the top line of the opening (or side line, in the vertical overhang case) to the line where the overhang begins and L the overhang length (Fig. 2). The same values have been taken for the left side, right side and double side vertical overhangs. 


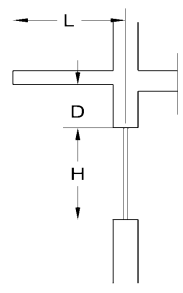

Figure 2: Overhang's Geometry

\section{Source(s): CTE DB HE 1 (Appendix E. Table E.11)}

Regarding returns, the following values have been handled: $0.10,0.15,0.295,0.60$ and 1.35 $\mathrm{m}$. Although, the last two values exceed the wall thickness where the opening is positioned, this possibility of setting back the opening beyond that limit has also been studied, because an adequate design might make it possible.

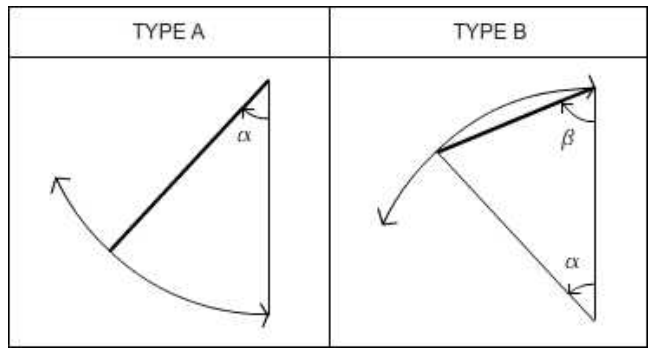

Figure 3: Awnings' geometry

Source(s): CTE DB HE 1, Appendix E. Table E.14

The vertical and horizontal louver blinds have been shaped with the following values: slat inclination angle $0^{\circ}, 30^{\circ}$ and $60^{\circ}$, with a depth of $0.05 \mathrm{~m}$ and separation distance between slats $0.03 \mathrm{~m}$.

Finally, the awnings were analysed following the two cases in CTE Appendix E Table E.14. Some difficulties have arisen in its modelling as LIDER does not take this analysis into consideration. Awnings and overhangs were simulated with different inclination angles $\left(\alpha=30^{\circ}\right.$, $45^{\circ}$ and $60^{\circ}$ - type A; $\beta=75^{\circ}, 67^{\circ}, 5^{\circ}$ and $60^{\circ}$ - type B) (Fig. 3). However, this analysis is inaccurate in terms of transmissivity.

Frame air permeability ranges considered limit values according UNE-EN 12207:2000 (AENOR 2000) classification for permeability of frames: type $1\left(50 \mathrm{~m}^{3} / \mathrm{h} \mathrm{m}^{2}\right)$, type $2\left(27 \mathrm{~m}^{3} / \mathrm{h}\right.$ $\left.\mathrm{m}^{2}\right)$, type $3\left(9 \mathrm{~m}^{3} / \mathrm{h} \mathrm{m}^{2}\right)$ and type $4\left(3 \mathrm{~m}^{3} / \mathrm{h} \mathrm{m}^{2}\right)$.

Infiltrations have been included as additional increments on the air change rates required of $0.50 / \mathrm{h}, 1 / \mathrm{h}$ and $2 / \mathrm{h}$.

The basic requirements of ventilation regarding air renovation rates have been evaluated following the criteria in the Basic Document HS 3 of Indoor Air Quality in the CTE (IETCC 2010c). The generic space has been considered as a room that must provide fresh outside air supplied through the window, for this reason $\mathrm{U}$ glazing has been penalized, calculating a new $\mathrm{U}$ value for this purpose (Ventilator $\mathrm{U}=3.90 \mathrm{~W} / \mathrm{m} 2 \mathrm{~K}$, model THL 100 of RENSON). LIDER program does not include data for these devices. The minimum ventilation rate required has been calculated for three cases of occupation: small bedroom, $(1$ person $-5 \mathrm{l} / \mathrm{s}=0.67 / \mathrm{h})$, main room $(2$ people $-10 \mathrm{l} / \mathrm{s}=1.33 / \mathrm{h})$ and living room $(4$ people $-12 \mathrm{l} / \mathrm{s}=1.6 / \mathrm{h})$. 


\section{Results}

LIDER has calculated heating and cooling energy demand of the 430 cases described in section 2. After that, for each category and by orientation, the differences between demand percentages for heating and cooling due to the modifications in the parameters under analysis have been calculated. The calculated differences correspond to maximum values of energy demand variation, as minimum and maximum demand results for each category have been considered when calculating them. These differences, obtained in percentage units, have been analysed in terms of potential, that is to say, considering them as the reduction in energy demand that might exist if studied parameters are carefully considered when openings are being designed. Table 2 shows the results corresponding to the group of variables related to intrinsic architectural and constructive properties in terms of potential variation in heating and cooling energy demand due to modifications in this group, and Table 3 shows the results related to architectonic and constructive elements of indoor environmental control in the same terms, but for the parameters of this second group.

In general, the best results with regard to the main potential performance on energy demand are those for cooling demand. Furthermore, they are better in the group of variables related to opening intrinsic properties than in the control elements one.

Table 2 shows how the main potential performance is in the dimensional category for cooling demand. The obtained variation percentages stand around maximum values of $140 \%$ in orientation W, E, SW and SE (from greater to lower potential), and around minimum values of $65 \%$ in $\mathrm{S}$ and $\mathrm{N}$. On solar radiation performance category the results for cooling are between a maximum of $47 \%(\mathrm{E})$ and a minimum of $23 \%(\mathrm{~N})$, whereas on materials category cooling results range from $43 \%(\mathrm{~W})$ to $21 \%(\mathrm{~N})$. From these results, the most noteworthy are the following: cooling demand might be reduced up to $149 \%$ acting over parameters of dimensions category (W), up to $47 \%$ acting over parameters of solar radiation category (E) and up to $43 \%$ acting over parameters of materials category $(\mathrm{W})$.

With regard to heating demand, the variation reaches maximum values between $15-18 \%$ in the South in the three categories (dimensions, solar radiation performance and materials), followed very close by SE and SW. And minimum values around 5-9\% in the other orientations $(\mathrm{N}, \mathrm{E}$ and $\mathrm{W})$ for the three categories. From these results we can conclude that heating energy demand might be reduced up to $18 \%$ acting over the dimensions category, up to $15 \%$ acting over solar radiation category and up to $15 \%$ over materials categories. 
Table 2: Potential variation of heating and cooling energy demand obtained acting over intrinsic architectural and constructive properties of openings

\begin{tabular}{|c|c|c|c|c|c|c|c|}
\hline$\Delta \%$ Energy & North & East & Southeast & South & Southwest & West & Average \\
\hline \multicolumn{8}{|l|}{ Dimensions } \\
\hline Heating & 7 & 8 & 16 & 18 & 16 & 7 & 12 \\
\hline Cooling & 64 & 143 & 138 & 68 & 142 & 149 & 117 \\
\hline \multicolumn{8}{|c|}{ Solar radiation performance } \\
\hline Heating & 5 & 9 & 13 & 15 & 12 & 8 & 10 \\
\hline Cooling & 23 & 47 & 46 & 39 & 37 & 38 & 38 \\
\hline \multicolumn{8}{|l|}{ Materials } \\
\hline Heating & 5 & 8 & 13 & 15 & 12 & 7 & 10 \\
\hline Cooling & 21 & 41 & 40 & 35 & 37 & 43 & 36 \\
\hline
\end{tabular}

Table 3 shows how the best performance is obtained on the shading components for cooling demand. Values obtained in the case of horizontal and vertical louver blinds are around $80 \%$ for all orientations (except for $\mathrm{N}$, which is not analysed), followed by percentages around $55 \%$ for awnings, $45 \%$ for overhangs, and $15 \%$ for returns. From these results, the most noteworthy are the following: cooling energy demand might be reduced up to $85 \%$ using horizontal (E, W) and vertical louver blinds (E, SE), up to $63 \%$ using awnings (E, W), up to $47 \%$ using overhangs (SE) and up to $16 \%$ using returns (SE). The worst results are for ventilation, between $0.20-2.00 \%$.

With regard to the heating demand, the best results are again for horizontal and vertical louver blinds, with values fluctuating around $45 \%$, followed by awnings around $25 \%$, overhangs with percentages between $10-20 \%$, returns between $5-12 \%$, and finally, ventilation between 4$11 \%$. That indicates potential reductions of heating energy demand up to $63 \%$ (S) using properly horizontal and vertical louver blinds, up to $37 \%$ (S) with awnings, up to $20 \%$ (SE, S, SW) with overhangs, up to $12 \%(\mathrm{~S})$ with returns and up to $11 \%(\mathrm{~S})$ with ventilation. In the case of ventilation, the most remarkable is the difference between the results according to different occupancy patterns. 
Table 3: Potential variation of heating and cooling energy demand obtained by acting over openings elements of indoor environmental control

\begin{tabular}{|c|c|c|c|c|c|c|c|}
\hline$\Delta \%$ Energy & North & East & Southeast & South & Southwest & West & Average \\
\hline \multicolumn{8}{|l|}{ Overhangs } \\
\hline Heating & - & 10 & 20 & 20 & 20 & 10 & 16 \\
\hline Cooling & - & 46 & 47 & 40 & 44 & 44 & 44 \\
\hline \multicolumn{8}{|l|}{ Returns } \\
\hline Heating & - & 5 & 8 & 12 & 8 & 5 & 7 \\
\hline Cooling & - & 13 & 16 & 13 & 11 & 15 & 14 \\
\hline \multicolumn{8}{|c|}{ Horizontal louver blinds } \\
\hline Heating & - & 30 & 48 & 63 & 48 & 30 & 44 \\
\hline Cooling & - & 85 & 82 & 75 & 82 & 85 & 82 \\
\hline \multicolumn{8}{|c|}{ Vertical louver blinds } \\
\hline Heating & - & 30 & 51 & 60 & 48 & 30 & 44 \\
\hline Cooling & - & 85 & 85 & 80 & 80 & 80 & 82 \\
\hline \multicolumn{8}{|c|}{ Awnings type A } \\
\hline Heating & - & 15 & 30 & 37 & 30 & 15 & 25 \\
\hline Cooling & - & 63 & 60 & 45 & 60 & 63 & 58 \\
\hline \multicolumn{8}{|c|}{ Awnings type $B$} \\
\hline Heating & - & 13 & 27 & 28 & 27 & 13 & 21 \\
\hline Cooling & - & 56 & 54 & 42 & 54 & 56 & 53 \\
\hline \multicolumn{8}{|l|}{ Ventilation } \\
\hline \multicolumn{8}{|l|}{ Heating } \\
\hline$(1 o c)$ & 4 & 4 & 6 & 6 & 6 & 5 & 5 \\
\hline$(2 o c)$ & 6 & 7 & 9 & 10 & 9 & 7 & 8 \\
\hline$(4 o c)$ & 7 & 9 & 10 & 11 & 10 & 9 & 9 \\
\hline \multicolumn{8}{|l|}{ Cooling } \\
\hline$(1 \circ c)$ & 0.20 & 1 & 1 & 0.70 & 0.50 & 0.60 & 0.67 \\
\hline$(2 o c)$ & 0.30 & 1.70 & 1.70 & 1.10 & 0.90 & 1 & 1,12 \\
\hline$(4 o c)$ & 0.40 & 2 & 2 & 1.20 & 1 & 1.20 & 1.30 \\
\hline
\end{tabular}

\section{Discussion}

The following graphs show some of the more significant cases which have been analysed in this study.

Figure 4 shows how the alterations introduced in the window-to-wall ratio and in the frame proportion in West orientations produces a fluctuation in energy demand of up to $149 \%$ for cooling, with a maximum value of $218 \%$ demand for opening ratio $>60 \%$ and a frame proportion of $10 \%$; and a minimum value of $69 \%$, for opening ratio $<20 \%$ and a frame proportion of $40 \%$. 
These results reveal that, introducing different values for these two parameters, a variation of $149 \%$ in the refrigeration energy demand might be obtained.

Meanwhile in heating demand, this variation gets to the maximum value of $7 \%$, with values between $71-78 \%$ for the cases that appear in Figure 5.

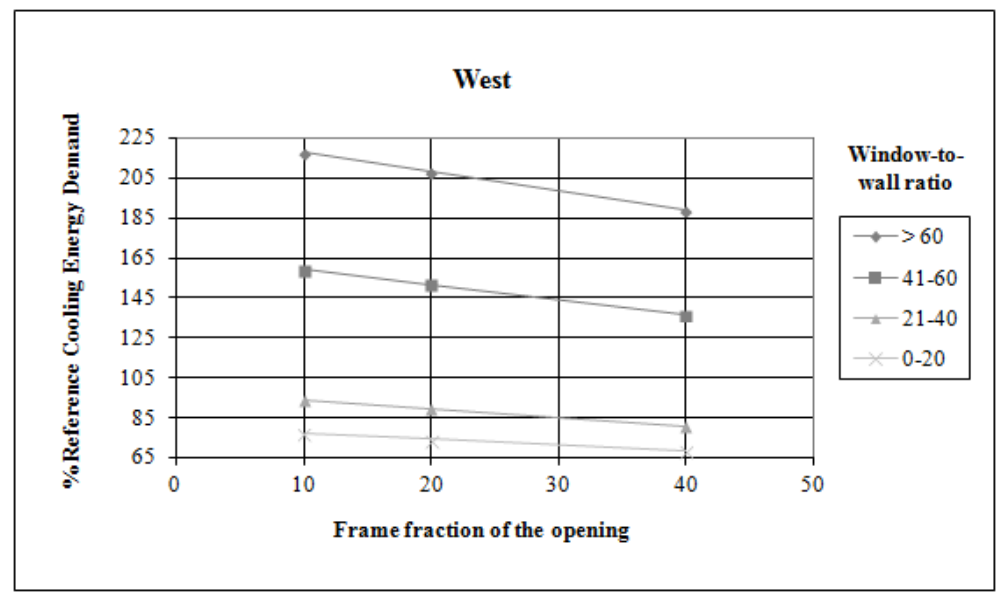

Figure 4: Variation on cooling energy demand for the Dimensions category in Western orientation.

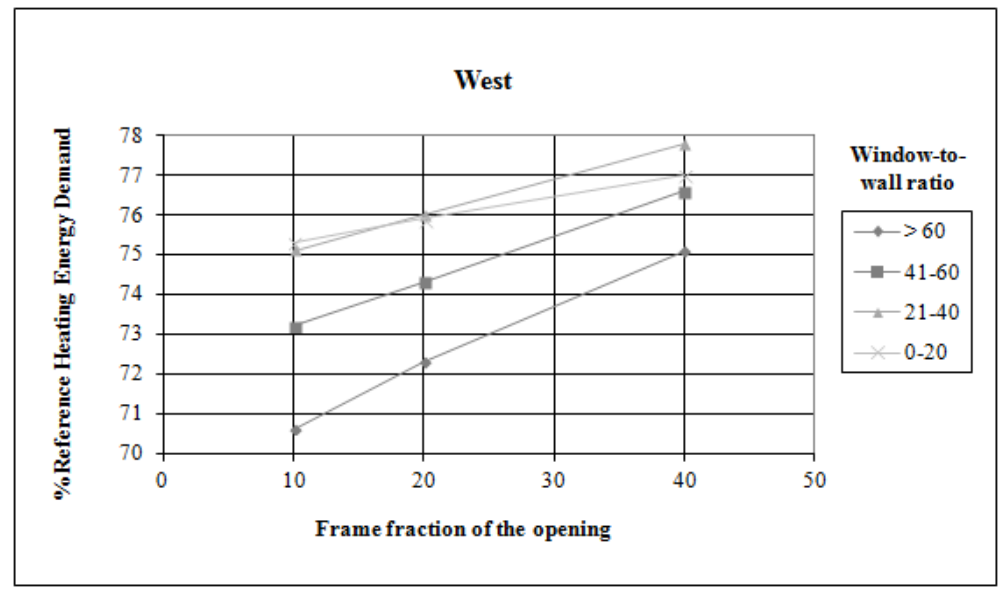

Figure 5: Variation on heating energy demand for the Dimensions category in Western orientation.

Figure 6 shows the Shading Elements category, when sun protective elements are added to the opening such as horizontal fixed louver blinds in the Western orientation, variations in heating energy demand of $30 \%$ and in cooling of $85 \%$ will be obtained, with energy demand values between $63-93 \%$ for heating and between $13-98 \%$ for cooling. The best outcome for these cases is found in energy demand for cooling, where the incorporation of horizontal louver blinds to an opening changes demand from $98 \%$ to $20 \%$.Therefore, there will be a reduction of $78 \%$ in energy demand for refrigeration. The results are very similar for vertical louver blinds and the other orientations E, SE, S and SW. 


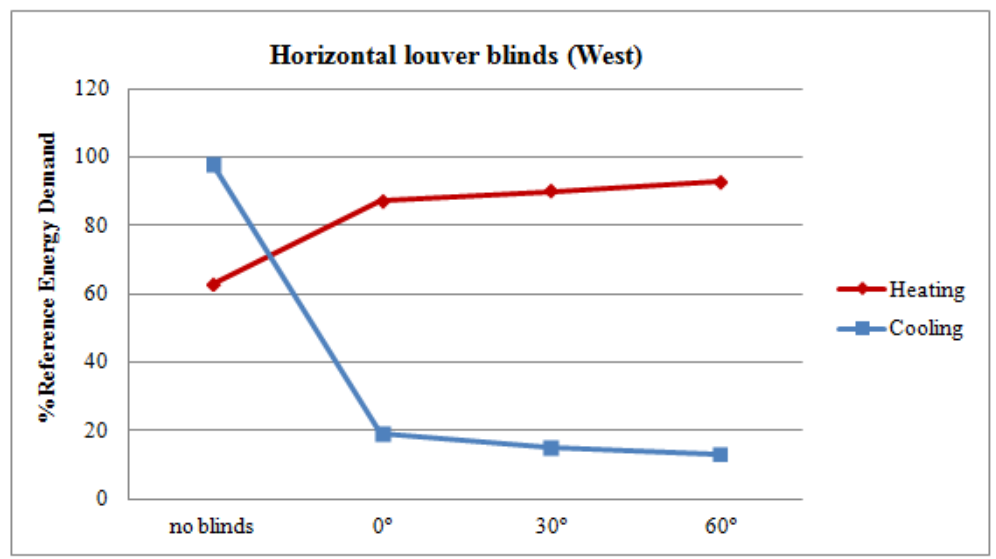

Figure 6: Variation on cooling and heating energy demand for the Shading Elements category horizontal louver blinds in Western orientation.

Figures 7 and 8 show that in those cases analysed under the Solar Radiation Performance category, even for the North orientation, the alteration in parameters such as frame degree of absorption (frame colour) and glazing g-value produces significant variations of the energy demand percentages for cooling and heating. Values between $78-83 \%$ are obtained for the heating case (Fig. 7) and between $65-88 \%$ for cooling (Fig. 8); in other words, variations reaching $5 \%$ for heating and $23 \%$ for cooling.

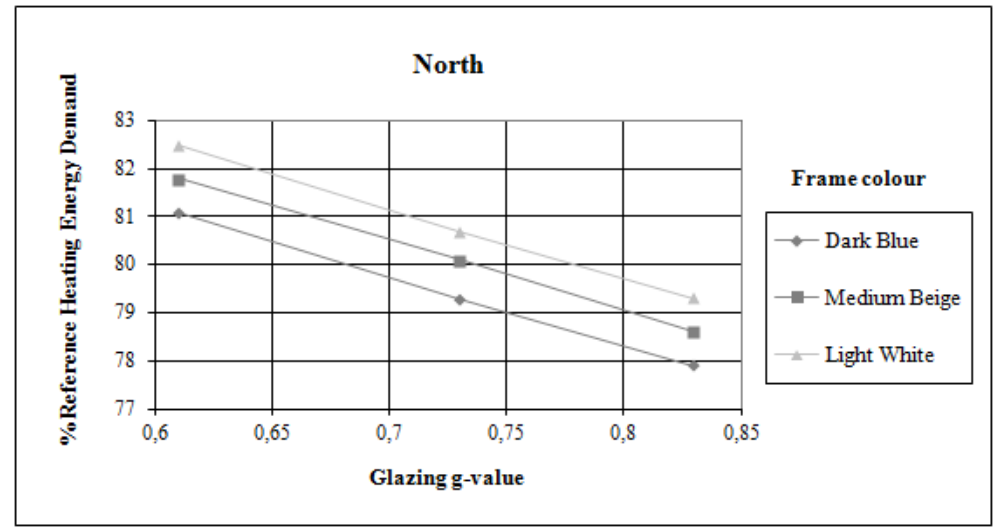

Figure 7: Variation on heating energy demand for the Solar Radiation Performance category in Northern orientation. 


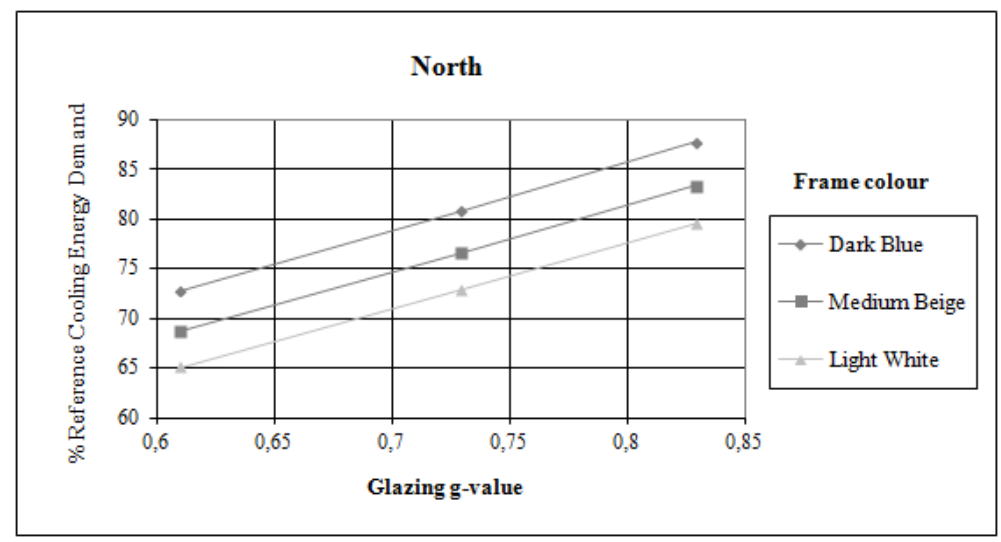

Figure 8: Variation on cooling energy demand for the Solar Radiation Performance category in Northern orientation.

Figures 9 and 10 show the cases analysed in the Materials category for the South orientation. The use of different combinations of frame U-value, glazing U-value and glazing g-value leads to variations in the heating demand that fluctuate between $70-85 \%$, that is, variations of $15 \%$ in heating and between $47-82 \%$ in cooling, that is up to $35 \%$.

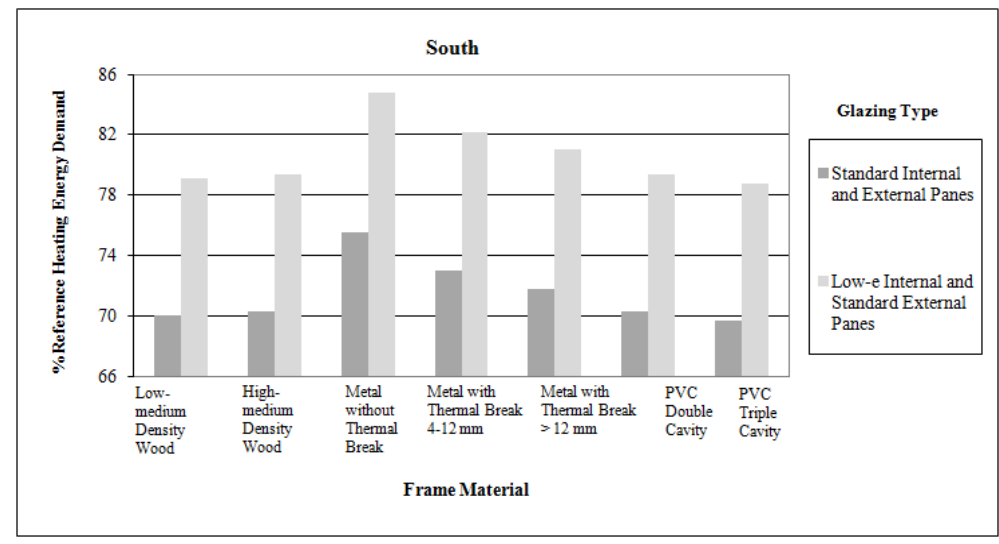

Figure 9: Variation on heating energy demand for the Materials category in Southern orientation. 


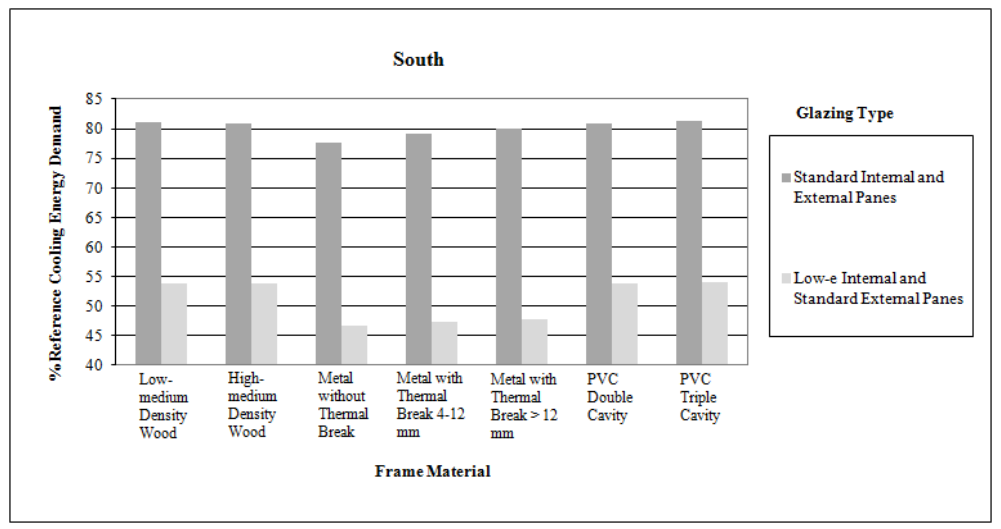

Figure 10: Variation on cooling energy demand for the Materials category in Southern orientation.

The results of this research are useful to optimize openings performance in every façade. They can guide the decision-making process, prioritizing between categories and bioclimatic needs of every façade. According to these findings, the greatest potential for energy savings through openings is in cooling demand. The priority order is as follows: 1st Dimensions, 2nd Shading elements, 3rd Solar radiation performance, 4th Materials and 5th Ventilation. As shown in tables 2 and 3, the potential for energy savings in heating demand is less, but also significant. In this case the order of priority varies slightly: 1st Shading elements, 2nd Dimensions, 3rd Solar radiation performance, 4th Materials and 5th Ventilation. In solar radiation performance and materials categories dimensions the fluctuation is very similar.

As with regard to the group of intrinsic architectural and constructive properties of opening categories, the potential in cooling demand is more relevant in E, SE, W and SW orientations than in $\mathrm{N}$ or $\mathrm{S}$ ones. In heating demand, the potential is more relevant in SE, S and SW orientations than N, E and $\mathrm{W}$ ones. For the opening elements of indoor environmental control group, the potential in cooling demand is more relevant in E, SE, W and SW orientations. In heating demand, the most relevant potential is in S, followed by SE and SW.

In view of the results, we can say that, generally speaking, what is favourable for heating demand is negative for cooling and vice versa. The contradictions between the construction solutions to be applied in winter and summer conditions in Southern European countries, such as Spain, with mild winters and very warm summers, make it necessary to adopt standard criteria that will facilitate activating and deactivating shading components according to the seasonal conditions (Leal and Maldonado 2008, 217-227). This need, together with an adequate architectural design in openings, may as well contribute to solve the climatic problems they have to tackle, and thus bringing significant changes in indoor temperature. Along this line, future research may pave the way for the incorporation of low-tech systems devised to improve comfort conditions in Mediterranean countries.

\section{Conclusions}

1. It has been demonstrated the significant influence on energy demand achieved with the modification of the 14 opening characteristic parameters which shows the great potential that openings have to control energy consumption of indoor environment, when there is a careful design regarding bioclimatic criteria. 
2. The variation range on the Dimensions category can reach values up to $150 \%$ in cooling demand and up to $20 \%$ in heating, altering aspects such as window-to-wall ratio and frame percentage.

3. The variation percentage in the Shading Components goes up to $85 \%$ in cooling demand and to $60 \%$ in heating, altering overhangs and returns, horizontal and vertical louver blinds and awnings.

4. In the Solar Radiation Performance and the Materials categories, variation goes up to $50 \%$ in cooling demand and $15 \%$ in heating, altering parameters such as orientation, frame degree of absorption, g-value of glazing and U-value of frame and glazing.

5. Finally, in the Ventilation category, the greatest range reached is 10\% in heating demand and $2 \%$ in cooling demand, modifying window frame air permeability, required air change rate and infiltration.

The conclusions of this analysis are more relevant in qualitative than in quantitative terms; particularly, numerical results might vary in different case studies. It is also necessary to consider that the onset hypotheses that have been used, as well as the hypothesis of LIDER software together with its default values might influence the results. For example, in the ventilation category, LIDER does not include in its database the actual data about wind direction because there are not reliable data for all the Spanish towns, so the same direction is considered in all cases (AICIA 2009b).

The variation in heating energy demand by means of the different openings under study would reduce this demand by $10-60 \%$. As regards cooling consumption, low technology solutions applied to openings, such as the ones analysed in this article, might reduce or even eliminate completely that demand while, at the same time, they improve comfort. Both, new buildings and refurbishment regulations should allow projects to explore all the potential of openings in energy demand reduction: dimensions, solar radiation performance, materials, shading elements and ventilation. All of them should be considered independently for every orientation to optimize openings contribution to energy savings. Shading elements must be controlled depending on schedules to achieve their optimum performance, thus a combination of static and dynamic elements is advisable for optimizing heating and cooling demand in every season.

\section{Acknowledgement}

We would like to thank Ingrid Chaires, a student of MIT Spain Program Intership, for her collaboration, and $\mathrm{M}^{\mathrm{a}}$ Jesús González Díaz and Carmen Alonso Ruiz-Rivas for their advice and support. Thank you also to José Luis Molina Félix, Christian Suárez Soria and Álvaro Ruiz Pardo from Grupo de Termotecnia of Universidad de Sevilla for their comments and explanations about the software used in the research.

This research study has been developed in the framework of the "Sustainable Refurbishment Project", co-financed by CDTI (Centro para el Desarrollo Tecnológico e Industrial) and the company's partners on the project. The first author wants to express her acknowledgment for the scholarship for training research staff of the Technical University of Madrid funded by the project. 


\section{REFERENCES}

AENOR. 2000. Puertas y Ventanas. Permeabilidad Al Aire. Clasificación. UNE-EN 12207. Madrid: AENOR.

AICIA. 2009a. Condiciones De Aceptación De Procedimientos Alternativos a LIDER y CALENER. Calificación De Eficiencia Energética De Edificios. Madrid: IDAE (Instituto para la Diversificación y Ahorro de la Energía) y Ministerio de Vivienda.

2009b. Condiciones De Aceptación De Procedimientos Alternativos a LIDER y CALENER. Anexos. Madrid: IDAE (Instituto para la Diversificación y el Ahorro de la Energía) y Ministerio de Vivienda.

Cuchí, Albert. 2010. Cambio Global España 2020/50. Sector Edificación. Madrid: Green Building Council España, Asociación Sostenibilidad y Arquitectura y Centro Complutense de Estudios e Información Medioambiental de la Fundación General de la Universidad Complutense de Madrid.

Cuevas, Cristian, Adelqui Fissore, and Nestor Fonseca. 2010. "Natural Convection at an Indoor Glazing Surface with Different Window Blinds." Energy and Buildings 42 (10): 1685 1691.

Dalenback, JO. 1996. "Solar Energy in Building Renovation." Energy and Buildings 24 (1): 3950.

Erell, E., Y. Etzion, N. Carlstrom, M. Sandberg, J. Molina, I. Maestre, E. Maldonado, V. Leal, and O. Gutschker. 2004. ""SOLVENT": Development of a Reversible Solar-Screen Glazing System." Energy and Buildings 36 (5): 467-480.

Fissore, Adelqui and Néstor Fonseca. 2007. "Experimental Study of the Thermal Balance of a Window, Design Description." Building and Environment 42 (9): 3309-3321.

2007. "Measurement Results and Experimental Analysis Study of the Thermal Balance of a Window." Building and Environment 42 (10): 3570-3581.

IDAE. "Factores De Conversión Energía Final - Energía Primaria y Factores De Emisión De CO2 - 2011." Instituto para la Diversificación y Ahorro de la Energía y Ministerio de Industria, Turismo y Comercio, http://www.idae.es.

Instituto de Ciencias de la Construcción Eduardo Torroja (Centro Superior de Investigaciones Científicas). 2010. "Catálogo De Elementos Constructivos Del CTE." Ministerio de Fomento. Gobierno de España, www.codigotecnico.org.

2010. "Código Técnico De La Edificación. Documento Básico De Ahorro De Energía. HE 1: Limitación De La Demanda Energética." Ministerio de Fomento. Gobierno de España, www.codigotecnico.org.

2010. "Código Técnico De La Edificación. Documento Básico De Salubridad. HS 3: Calidad Del Aire Interior." Ministerio de Fomento. Gobierno de España, www.codigotecnico.org.

International Energy Agency. 1999. Solar Renovation Concepts and Systems, IEA Solar Heating and Cooling Programme Task 20 Solar Energy in Building Renovation, Subtask F: Improvement of Solar Renovation Concepts and Systems, Technical Report Task 20 STF N12.

Leal, V. and E. Maldonado. 2008. "The Role of the PASLINK Test Cell in the Modelling and Integrated Simulation of an Innovative Window." Building and Environment 43 (2): 217-227.

Luxán García de Diego, Margarita de. 2009. Actuaciones Con Criterios De Sostenibilidad En La Rehabilitación De Viviendas En El Centro De Madrid : Aplicación Para Los Barrios De Hortaleza, Jacinto Benavente, Lavapiés, Chamberí, Justicia, Sol, Tetuán, Palos De Moguer, Arganzuela y Áreas De Salamanca y Goya. Madrid: Empresa Municipal Vivienda y Suelo del Ayuntamiento de Madrid. 
Mustieles, F., La Roche, P., Machado, M., de Oteiza, I., Indriago, J., González,R. 1998. "Cerramientos Bioclimáticos Para Climas Cálidos Húmedos: La Cuarta Vivienda." Informes De La Construcción 49 (453).

Urbikain, M. K. and J. M. Sala. 2009. "Analysis of Different Models to Estimate Energy Savings Related to Windows in Residential Buildings." Energy and Buildings 41 (6): 687-695.

Voss, K. 2000. "Solar Energy in Building Renovation - Results and Experience of International Demonstration Buildings." Energy and Buildings 32 (3): 291-302.

Yáñez Parareda, Guillermo. 2008. Arquitectura Solar e Iluminación Natural: Conceptos, Métodos y Ejemplos. Madrid: Munilla-Lería. 